\title{
The impact of the cigarette market opening in Taiwan
}

\author{
C P Wen, T Y Cheng, M P Eriksen, S P Tsai, C C Hsu
}

Tobacco Control 2005;14(Suppl I):i4-i9. doi: 10.1136/tc.2004.008516

\begin{abstract}
Objective: To assess the effect of the opening of the Taiwanese cigarette market on cigarette consumption, changes in market share, and the effects on tobacco control efforts.

Methods: With the use of key word "Taiwan", the Legacy Tobacco Documents Library of the University of California, San Francisco, was searched for internal documents related to smuggling activities, promotion of light cigarettes, and market share analyses in Taiwan. Age adjusted smoking rates and cigarette and betel quid consumption before and after market opening were compared.

Results: By 2000, the market share of imported cigarettes increased from less than $2 \%$ in 1986 to nearly $50 \%$, and per capita cigarette consumption increased $15 \%$ following market opening. Because of the sharp increase in smuggling, with contraband cigarettes being as popular as legal imports, and the rapid proliferation of retail outlets, such as betel quid stalls, the market penetration by foreign tobacco companies was greater in Taiwan than among the other Super 301 Asian countries. Aggressive cigarette marketing strategies were associated with a $6 \%$ increase in adult male smoking prevalence, and with a $13 \%$ increase in the youth rate, within three years after market opening. The market opening also had an incidental effect on increasing the popularity of betel quid. Betel quid chewing has since become a major public health problem in Taiwan.

Conclusion: The opening of the cigarette market in 1987 had a long lasting impact on Taiwan. It increased smoking prevalence and the market has become dominated by foreign companies. The seriousness of smuggling and its associated loss of revenue by the government, the extent of increased youth smoking and its associated future health care costs, and the increased use of betel quid and the associated doubling of oral cancer mortality rates each pose significant problems to Taiwan. However, the market opening galvanised anti-smoking sentiment and forced the government to initiate and intensify a series of tobacco control efforts.
\end{abstract}

See end of article for authors' affiliations

Correspondence to: Chi Pang Wen, National Health Research Institutes, 35 Keyan Road, Zhunan Town, Miaoli County, Taiwan 350; Cwengood@ nhri.org.tw

F or 50 years between 1895 and 1945, Taiwan was under Japanese colonial rule, and the government run Taiwan Tobacco and Wine Monopoly Bureau (the Monopoly Bureau) produced relatively few cigarettes until the early 1940s when it reached 0.5 million cases (10 000 cigarettes/ case) a year. ${ }^{1}$ The second world war soon interrupted this level of production when the Chinese took over the Monopoly Bureau. Production returned to pre-war levels by 1950, and tripled the number of cigarettes produced over the next 30 years, from 1 million cases in 1955 to 3 million cases in 1985 , outpacing the increase in population. ${ }^{1}$ The contribution of cigarettes to the total national revenue was $10 \%$ in 1970, but decreased steadily afterwards, to $8 \%$ in $1975,5 \%$ in $1980,2 \%$ in 1990 , and $1 \%$ in $2000,{ }^{1}$ not because of reducing tobacco consumption, but mainly because of the expanding tax base from personal income and general tax during periods of rapid economic development. ${ }^{2}$

Taiwan grows relatively little tobacco. Even when it peaked in 1985, production was only $25000000 \mathrm{~kg}$, covering 10000 hectares (24 700 acres) with up to $90 \%$ of tobacco used in cigarette production coming from imported tobacco leaf. ${ }^{1}$ The Monopoly Bureau contracted with some 10000 licensed retail outlets to market cigarettes in the 1970s and 1980s. ${ }^{1}$ Other than these authorised outlets, no other retailers could legally sell tobacco. Before the 1987 market opening, foreign cigarettes constituted less than $2 \%$ of overall market share. ${ }^{1}$

The opening of the cigarette market in 1987 marked a turning point for the monopoly system. Under the threat of retaliatory sanctions by the US government, the Taiwan government, like its counterparts in Japan, South Korea, and Thailand, was forced to give up its century long monopoly control of the cigarette market. US and European tobacco companies were allowed to promote and market cigarettes and tariffs were reduced. ${ }^{3}$ Foreign tobacco companies transplanted their skills and experience in marketing cigarettes at point of sale (POS) retail outlets and in advertisements in Taiwanese magazines. ${ }^{4}$

Based on US law (section 301 of the 1974 Trade Act and its subsequent amendments of the 1984 Trade and Tariff Act and the Omnibus Trade and Competitiveness Act of 1988, now known as Super $301^{5}$ ) market opening was intended to eliminate unfair trading practices and to reduce the trade imbalance for the USA. Taiwan resisted the opening and protested to the USA based on the concern that the market opening would have an adverse effect on public health. ${ }^{6}$ However, some argued that, based on trade negotiations in $1992,{ }^{3}$ the motivation of the Taiwan government for such resistance stemmed as much from fear of losing market share to foreign competitors as it did from public health concerns. The sentiments in the "tobacco war" waged at that time came more from concerns regarding national economic sovereignty than tobacco hazards. ${ }^{6}$ As a result, the long term health impact of the market opening has never been directly assessed. The purpose of this study is to assess the effect of the opening of the cigarette market on cigarette consumption, changes in market share, and the effects on tobacco control efforts.

\section{METHODS}

Age adjusted smoking rates and cigarette and betel quid consumption before and after market opening were compared. These data were obtained from surveys conducted by the Taiwan Monopoly Bureau, the Taiwan National Health

Abbreviations: JTI, Japan Tobacco Inc; NHIS, National Health Interview Survey; POS, point of sale 
Interview Survey (NHIS 2001), ${ }^{89}$ and the Directorate-General of Budget, Accounting and Statistics. ${ }^{10}$ Data for market share came from the Taiwan Customs Office for Taiwan and Tobacco Control Country Profiles for other countries. ${ }^{11}{ }^{12}$ With the use of "Taiwan" as the key word, Legacy Tobacco Documents Library of the University of California, San Francisco, was searched for industry internal documents ${ }^{13}$ related to smuggling activities, promotion of light cigarettes, and market share analyses in Taiwan. A detailed description of this search has been presented elsewhere. ${ }^{4}$

\section{RESULTS}

\section{Aggressive strategies for advertisement and promotion}

As there were reports that limited cigarette advertising existed among some countries with monopoly system, ${ }^{14}$ the advertising under the monopoly system in Taiwan, if any, had been largely informational. ${ }^{15}$ As a result of the pressure from the USA, Taiwan signed an agreement allowing foreign cigarettes to be advertised and promoted. ${ }^{3}$ On the surface, the concessions seemed quite limited, allowing up to 120 advertising insertions per company in magazines within a year, and restricting cigarette promotions to remain inside retail outlets. However, aggressive strategies such as the expanded use of unlicensed betel quid stalls in selling cigarettes, ${ }^{16}$ youth targeting, and brand stretching advertising, ${ }^{4}$ were employed and have achieved market share expansion by foreign tobacco companies well beyond that which would have been expected via traditional marketing. For example, within the five years 1995-2000, the total expenditures on all forms of advertising by foreign tobacco companies increased more than fivefold $(451 \%) .{ }^{4}$ Much of the expenditure was spent on brand stretching on the Mild Seven (Japan) and Davidoff (Germany) brands in television advertising. Such a practice is controversial, since no tobacco advertising on television is legally allowed. Limited by the number of licensed establishments, foreign tobacco companies sought new retail outlets and made use of tens of thousands of "unlicensed" POS locations. With additional businesses selling imported cigarettes, roadside stalls selling betel quid substantially boosted their fledgling betel quid business. ${ }^{16}$ To target the young and new smokers, foreign cigarette companies clearly stated their strategic plans and focused their business priorities on this relatively small but important market. ${ }^{17-21}$

\section{Promotion of light and mild cigarettes}

Light cigarettes were introduced to Taiwan at the time of the market opening. Foreign tobacco companies disproportionately promoted mild and light cigarettes, which not only attracted new and young smokers, but also intercepted smokers who might have otherwise quit. ${ }^{22}{ }^{23}$ The popularity of mild and light cigarettes almost certainly contributed to continued smoking and heavier smoking. ${ }^{22}$ Virginia Slims, ${ }^{24}{ }^{25}$ Mild Seven, ${ }^{17}$ and the Joe Camel Smooth campaign ${ }^{26}$ all emphasised the mild and smooth nature of light cigarettes, particularly catering to young and new smokers, but also to potential quitters. ${ }^{27}$ Anti-smoking campaigns by the government may have contributed to the popularity of light cigarettes, ${ }^{28}$ as smokers tried to reduce the health hazards of smoking, and believed that smoking light cigarettes would do so. ${ }^{22}$ The Monopoly Bureau did not produce any light cigarettes before 1988, and, in that first year, only $9 \%$ of domestic production was light cigarettes. ${ }^{1}$ Recognising that the majority of leading foreign brands were "light" and were capturing an increasing share of the market, the Monopoly Bureau responded by quickly increasing the production of light cigarettes to $30 \%$ of its sales by 1992 , reaching $100 \%$ by 2002. ${ }^{1}$ Although this appeared to be a major change, the purportedly light cigarettes produced by the Monopoly Bureau, when tested by a foreign competitor, were not ventilated $^{29}$ and had tar concentrations measured at or around 18-24 mg, ${ }^{30}{ }^{31}$ which were higher than the commonly used machine yield value of $15 \mathrm{mg}$ or lower for light cigarettes. $^{23}$ In the absence of technology to produce cigarettes with ventilation, the Monopoly Bureau had great difficulty in keeping the tar values low. As a result, the Monopoly Bureau, unable to compete in the light market, catered to older smokers and was viewed by smokers in Taiwan as the producer of strong flavoured regular cigarettes. $^{32}$ The market opening associated light cigarettes with imported cigarettes and placed the Monopoly Bureau at a disadvantage. As more and more smokers switched to "light" cigarettes, the strong flavoured domestic cigarettes lost appeal.

\section{Cigarette smuggling}

Although contraband cigarettes have always existed in Taiwan, ${ }^{1}$ they played a small role before the opening, partly because cigarettes were only available through licensed establishments, ${ }^{3}$ and smuggled products had no convenient retail outlets. The licensed establishments faced too large a risk to sell contraband cigarettes openly. This changed after the market opened. Foreign tobacco companies sought and established a network of retail outlets to sell their products, such as convenience stores and betel quid stalls. When betel quid stalls started selling both legal and contraband cigarettes, their business increased and more stalls were established. ${ }^{16}$ The confiscated quantity of smuggled cigarettes in 1990 was officially reported as roughly 10-fold the amount in 1986 (table 1). ${ }^{1}$ In a nationwide survey, 8\% of male adult smokers reported a preference for imported cigarettes in $1986,{ }^{8}$ reflecting the potentially small share of the contraband market. Once the market opened, smuggled cigarettes grew rapidly as smoker's preference for imports nearly tripled in $1987 .{ }^{32}$ According to industry documents, smuggled cigarettes equalled or even exceeded those legally imported ones and accounted for $15 \%(12 \%-18 \%)$ of the entire market by first half of 1990s (table 1).

\section{Increased consumption of betel quid}

Cigarettes were legally available only at licensed establishments in Taiwan, both before and after the market opened. ${ }^{1}$ The licensure authorisation came from the Monopoly Bureau and enforcement was simple when cigarettes made only by the Bureau were sold. The need for retail outlets increased almost overnight as a result of the 1987 market opening, and foreign tobacco companies expanded to the existing betel quid street vendors to sell cigarettes. ${ }^{33}$ US cigarette firms largely ignored permit requirements for these retail outlets and governmental authorities protested such violations to no

\begin{tabular}{|c|c|c|c|c|}
\hline & $\begin{array}{l}\% \text { of legal } \\
\text { import in } \\
\text { total markef* }\end{array}$ & $\begin{array}{l}\text { Quantity } \\
\text { confiscated }{ }^{*} / \\
\text { quantity } \\
\text { smuggled† }\end{array}$ & $\begin{array}{l}\% \text { of smuggled } \\
\text { in total import } \\
\text { (legal and } \\
\text { smuggled) }\end{array}$ & $\begin{array}{l}\% \text { of } \\
\text { smuggled } \\
\text { in total } \\
\text { market }\end{array}$ \\
\hline 1986 & $2 \%$ & $5 /$ not available & - & - \\
\hline 1988 & $20 \%$ & $45 / 553$ & $49 \%$ & $13 \%$ \\
\hline 1990 & $16 \%$ & $57 / 791$ & $58 \%$ & $18 \%$ \\
\hline 1992 & $28 \%$ & $130 / 708$ & $54 \%$ & $15 \%$ \\
\hline 1995 & $27 \%$ & $27 / 544$ & $34 \%$ & $12 \%$ \\
\hline
\end{tabular}

Unit: 1000 cases (1 case $=10000$ cigarettes) *Annual statistical report of the Monopoly Bureau. †British American Tobacco Company business review documents. ${ }^{39} 405051$ 


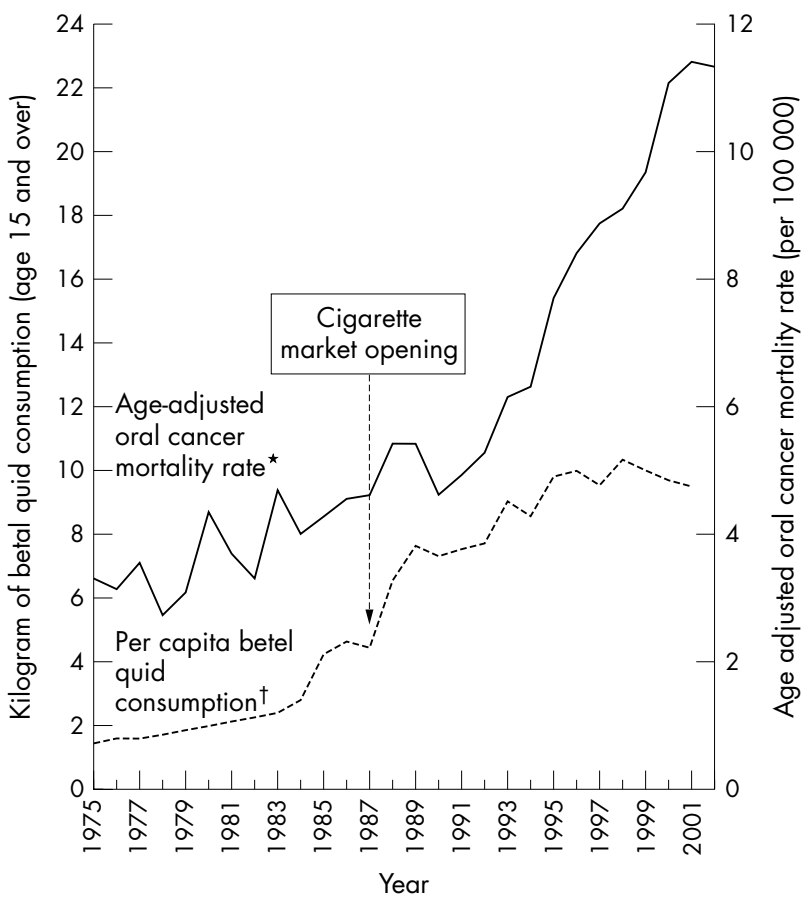

Figure 1 The association of betel quid consumption and male oral cancer mortality. * Vital statistics, Department of Health (1975-2002), age adjusted to year 2001 population. TStatistical Yearbook of Taiwan, Directorate-General of Budget, Accounting and Statistics (2002).

avail. $^{34}$ From the business perspective of the Monopoly Bureau, domestic cigarettes needed just as many retail outlets as foreign imports, and therefore started to share these stalls as common outlets. When a large number of these outlets came into business in a short period of time, licensure requirements became difficult to enforce. Since most betel quid chewers were also smokers, ${ }^{35}{ }^{36}$ the added cigarette business, which was many times larger than the betel quid market, boosted the business of these vendors. These new retail outlets initially attracted cigarette smokers, but betel quid users later. ${ }^{16}$ As a result, the number of betel quid stalls multiplied. As shown in fig 1, before the market was opened, per capita consumption of betel quid was low, at $2.0 \mathrm{~kg} /$ capita in 1980, and gradually increased to $2.8 \mathrm{~kg} / \mathrm{capita}$ in 1984 and to $4.6 \mathrm{~kg} / \mathrm{capita}$ in $1986 .^{37}$ The largest absolute increase $(3.0 \mathrm{~kg} /$ capita) occurred in a period of three years between 1986 (4.6 kg/capita) and 1989 (7.6 kg/capita) immediately after the market opened. Consumption in 2001 $(9.5 \mathrm{~kg} / \mathrm{capita})$ more than doubled the pre-opening figure. During this 15 year period, oral cancer also increased sharply; the age adjusted mortality rate more than doubled, from 4.56 per 100000 in 1986 to 11.42 per 100000 in 2001, and the number of deaths more than quadrupled, from 349 to 1436 , during the same time period. ${ }^{38}$

\section{Changes in market share}

As feared by the Monopoly Bureau, opening of the cigarette market in Taiwan dramatically increased the market share of imported cigarettes. In six years, imports increased from $2 \%$ of the cigarette market in1986 to $28 \%$ in $1992,{ }^{11}$ not counting smuggled cigarettes, and to $43 \%$ if smuggled cigarettes were included. ${ }^{39}$ By 2000 , nearly half $(48 \%)$ of all legal cigarettes came from outside of Taiwan (table 2). Compared to other Asian countries that opened their cigarette markets to imported cigarettes, Taiwan experienced the largest market penetration by foreign cigarette companies. The market share of foreign tobacco of the four Super
Table 2 Comparison of foreign market share changes among the four Asian Super 301 countries after market opening

\begin{tabular}{lllll}
\hline & & & South \\
Year market opened & (1987) & $\begin{array}{l}\text { Taiwan } \\
\text { (1987) }\end{array}$ & $\begin{array}{l}\text { Korea } \\
\text { (1989) }\end{array}$ & $\begin{array}{l}\text { Thailand } \\
(\mathbf{1 9 9 0 )}\end{array}$ \\
\hline Year before market opened & $5 \%$ & $2 \%$ & $0.1 \%$ & $1 \%$ \\
1990 & $13 \%$ & $16 \%$ & $5 \%$ & $1 \%$ \\
1993 & $19 \%$ & $33 \%$ & $6 \%$ & $3 \%$ \\
1995 & $18 \%$ & $27 \%$ & $14 \%$ & $5 \%$ \\
1998 & $30 \%$ & $38 \%$ & $8 \%$ & $13 \%$ \\
2000 & $24 \%$ & $48 \%$ & $9 \%$ & $18 \%$ \\
\hline
\end{tabular}

Sources: Annual statistical report of the Monopoly Bureau (Taiwan data)'; British American Tobacco Company ${ }^{39}$ (other countries in 1993) and Tobacco Control Country Profiles ${ }^{12}$ (other countries in 1990, 1995, 1998, 2000).

301 countries-Japan, Taiwan, South Korea, and Thailandin 2000 was $24 \%, 48 \%, 9 \%$, and $18 \%$, respectively (table 2 ). If Taiwan had the same market penetration as in South Korea, nearly $40 \%$ of the entire cigarette expenditure, or US $\$ 2$ billion a year, would not have been spent on imported cigarettes.

While the overall imported cigarette market share has dramatically increased, the US proportion of the market has gradually declined. ${ }^{11}$ This observation is somewhat ironic given that the market opening effort was entirely the result of pressure exerted by the US government. In 1987, at least 75\% of imported cigarettes were from the USA, ${ }^{11}{ }^{32}$ which reduced to $21 \%$ in 1995 and $10 \%$ in 2000 . The USA is now ranked fourth in imported cigarette market share, after Japan, UK, and Germany. A major reason for US cigarettes retreating in the1990s in Taiwan was the documented, aggressive smuggling by Japan Tobacco Inc (JTI) in the early 1990s. ${ }^{39} 40$ Japan was initially excluded from the cigarette market opening in Taiwan until $1994,{ }^{11}$ due to a long existing trade imbalance between Taiwan and Japan. Documents from several tobacco companies, including RJ Reynolds and British American Tobacco, showed $90 \%$ of all smuggled cigarettes to Taiwan in the first half of 1990 were from JTI. ${ }^{41} 42$ Smuggled JTI "Mild Seven" cigarettes accounted for nearly 10-20 times the company's legal quota, which came from a small JTI factory set up in Switzerland to produce the imports. ${ }^{39-41}$ Re-selling of Japanese contraband cigarettes into the market through auctioning by the government aided and abetted the rise of the Japanese market share. ${ }^{7}$ The US tobacco companies protested without avail against governmental action in not destroying those confiscated Japanese cigarettes. ${ }^{43}$

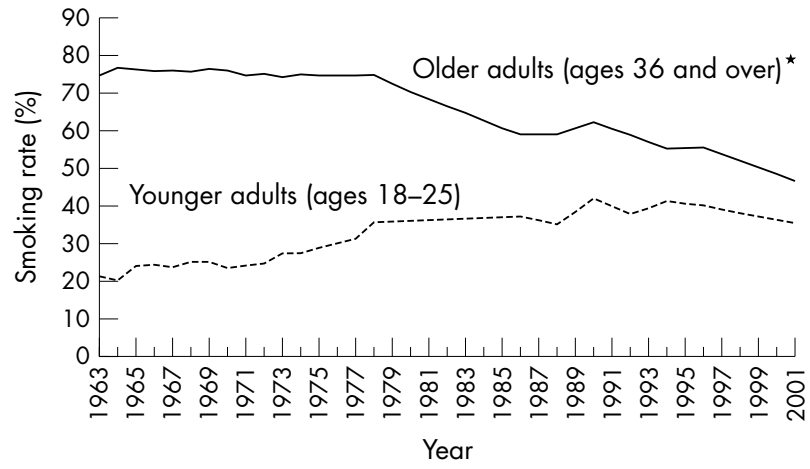

Figure 2 Male smoking rates for younger adults (aged 18-25) and older adults (aged 36 and over), 1963-2001. *Standardised to 2001 population. 


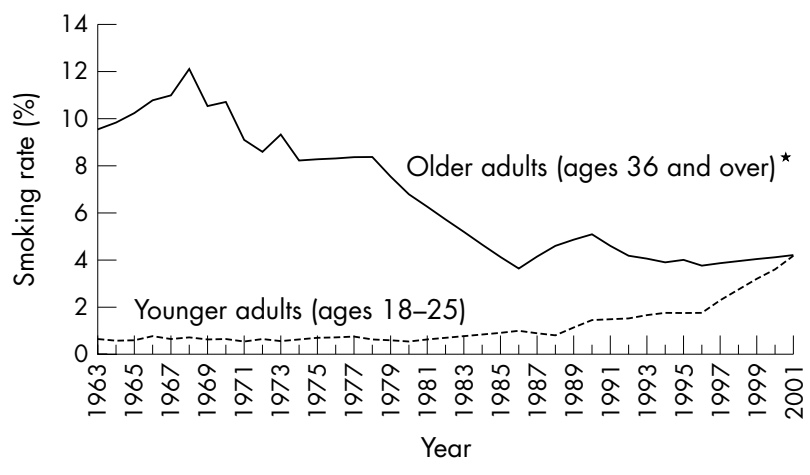

Figure 3 Female smoking rates for younger adults (aged 18-25) and for older adults (aged 36 and over), 1963-2001. *Standardised to 2001 population.

\section{Smoking rates}

Male smoking prevalence in those aged 35 and above was over $75 \%$ in early 1960s, and remained at that level into the 1970s (fig 2). ${ }^{8}$ The rates started to decline in the late 1970s, and the decline accelerated in the 1980s. When the market opened, the previous declining trend was reversed and the smoking rate increased by $6 \%$ within three years (19861990). Per capita consumption also increased, from 1604 cigarettes/year in 1986 to 1717 cigarettes/year in 1990, an increase of $7 \%$, and to 1840 cigarettes/year in 2000, an increase of $15 \%$ compared to 1986 levels. ${ }^{10}$

Female smoking prevalence was substantially lower than the male rate, around $8-12 \%$ in the 1960 s and 1970 s, and gradually declined afterwards (fig 3). Before market opening, female smoking prevalence was 3.6\% in 1986. Upon opening, the rate increased to $5.1 \%$ by 1990 , an increase of $42 \%$.

Smoking rates among younger men, aged 18-25, increased from $20 \%$ in early 1960 s to $35 \%$ in the late 1970 s (fig 2 ). This increase slowed in the1980s until the market opened in 1987. Following the market opening, there was an increase in smoking prevalence, with the increase being nearly double that seen among older adults $(37.3 \%$ in 1986 to $42.0 \%$ in 1990, an increase of $12.8 \%$ ). Among younger women, the rise after the market opened was even more pronounced, albeit smaller in absolute number, increasing from $0.9 \%$ in 1986 to $1.4 \%$ in 1990 , an increase of $56 \%$ (fig 3 ).

\section{ANTI-SMOKING INITIATIVES BY THE TAIWAN GOVERNMENT}

After the cigarette market was opened, the Taiwan government was stimulated to initiate many anti-smoking programmes, ${ }^{44}$ responding to the publicity of the "tobacco war". ${ }^{6}$ These activities included school based programmes in 1987 and 1991, collaboration with an anti-smoking non-governmental organisation on public campaigns for tobacco control, discontinuation of the four decade long rationing system of supplying free cigarettes to military personnel in 1991, a ban on smoking in public places such as governmental offices, classrooms or theatres and on public transport in 1995, and legal initiatives culminating in the enactment of the 1997 Tobacco Hazards Control Act that has comprehensive tobacco control policies. ${ }^{45}$ In 2002, an increase in cigarette taxes was levied on the low priced Taiwan cigarettes (14\% tax on an averaged price of US $\$ 1 /$ pack $){ }^{46}$ with a portion of the increased revenue dedicated to tobacco control programmes, amounting to 30 times the previous annual budget for tobacco control.

\section{DISCUSSION}

The opening of the cigarette market in 1987 has had a profound and sustained impact on Taiwan. The previously declining

\section{What this paper adds}

Within three years of the opening of the Taiwanese cigarette market to imports in 1987 aggressive marketing strategies led to $6 \%$ and $13 \%$ increases in adult male and youth smoking prevalence, respectively. Three out of four young people smoked imported brands in 2001. Market share of imported cigarettes grew from $2 \%$ to $50 \%$ in 15 years, the largest increase among Asian countries opening cigarette markets. The market opening also had an unanticipated effect of increasing the popularity of betel quid chewing, which has become a major public health problem in Taiwan. The forced opening of the cigarette market has galvanised the government into launching anti-smoking campaigns.

smoking rates reversed. There was a dramatic shift in market share toward purportedly lower tar, imported cigarettes. Smuggling increased and government lost revenue. Youth smoking increased, with an expected increase in future health care costs. Betel quid consumption has increased dramatically and the oral cancer mortality rate has doubled. Together, these factors have had an extremely negative effect on the public health in Taiwan. The findings of this study can serve as a valuable lesson to those countries, such as $\mathrm{China}^{47}$ and India, contemplating opening their cigarette market to the multinational tobacco companies. It would be of interest to undertake a further study on measures adopted by other super 301 countries on the extent of their success in resisting the penetration by foreign tobacco companies.

The four Super 301 countries were adversely affected by the opening of the cigarette market, with an average of $10 \%$ increase in per capita consumption than would otherwise have occurred without market opening. ${ }^{5}$ However, among these countries, Taiwan had the largest and most rapid increase in the market share of imported cigarettes. Aside from minor details, all four countries had similar agreements allowing tobacco companies to engage in various advertising and promotional activities, and yet the market share grew most in Taiwan. Reasons for this are complex, but the use of betel quid stalls to serve as cigarette retail outlets and smuggling caused by the closed market to JTI have played an important role.

The sudden and sharp increase in betel quid consumption immediately after cigarette market opening was totally unanticipated and has brought serious health consequences to Taiwan. The sharp increase in oral cancer mortality is a tragic effect of the market opening. The relatively short lag time between the time of consumption and the oral cancer deaths, roughly between 3-7 years (fig 1), has made the tragedy more visible. The oral cancer mortality rate in Taiwan was similar to that of the USA or Japan in the early 1980s, but the male rate in Taiwan has become five times higher in 2001, nearly the highest in the world.$^{38}{ }^{48}$ Because few women chew betel quid, their oral cancer rate remains as low as in the USA or Japan. ${ }^{38} 48$

The fact that market opening was associated with a sharp increase in smuggling is surprising, but the following factors may have facilitated such a phenomenon in Taiwan: sudden increase in retail outlets, increasing demand for foreign cigarettes, and more difficulty in identifying the contraband cigarettes by the government after the market opened.

Taiwan resisted the market opening during negotiations with the USA, but was reported to be mostly for financial concerns. ${ }^{3}$ While the Monopoly Bureau had lost some revenue due to decreased market share, ${ }^{1}$ this loss was offset by the government collecting additional tariffs on the increased volume of imported cigarettes. As cigarette consumption increased after the market opened, with higher 
tariffs collected from imported cigarettes, ${ }^{49}$ the total revenue by the government has continued to increase. ${ }^{1}$

Given such increased revenue in retrospect, the government would have had relatively little incentive to resist market opening based on financial considerations. There were others who benefited from market opening: the retail outlets, notably the convenience stores and the betel quid business, the media with their cigarette advertising and promotional revenues, the lobbying groups for the foreign tobacco companies, the intermediaries involved in the smuggling chains, and the foreign tobacco companies. The losers were quite obvious: the young smokers and the young betel quid chewers, and all citizens, who are expected to pay for the current and future medical care expenditures of smokers under National Health Insurance.

The market opening galvanised anti-smoking sentiment and stimulated the government to initiate and intensify a series of tobacco control efforts. Although a decade of tobacco control effort has contributed to making smoking increasingly socially unacceptable, these public health efforts have not reversed the harmful effects of market opening.

\section{Authors' affiliations}

C P Wen, T Y Cheng, C C Hsu, Division of Health Policy Research, National Health Research Institutes, Taipei, Taiwan

M P Eriksen, Institute of Public Health, Georgia State University, Atlanta, Georgia, USA

S P Tsai, University of Texas Health Science Center at Houston, School of Public Health, Houston, Texas, USA

Competing interests: none declared

\section{REFERENCES}

1 Monopoly Bureau. Taiwan tobacco and wine statistical yearbook. Taipei: Taiwan Tobacco and Wine Monopoly Bureau; 1961-2002.

2 Hsieh CR, Lin YS. The economics of tobacco control in Taiwan. In: Abedian I, Merwe R, Wilkins N, Jha P, eds. The economics of tobacco control: towards an optimal policy mix. Cape Town, South Africa: Applied Fiscal Research Centre, University of Cape Town, 1998.

3 US Department of Health and Human Services. Reducing tobacco use: a report of the Surgeon General. Atlanta, Georgia: US Department of Health and Human Services, Centers for Disease Control and Prevention, Office on Smoking and Health, 2000.

4 Wen CP, Chen T, Tsai YY, et al. Are marketing campaigns in Taiwan by foreign tobacco companies targeting young smokers? Tobacco Control 2005; 14(suppl I):i38-44.

5 Chaloupka FJ, Laixuthai A. US trade policy and cigarette smoking in Asia. National Bureau of Economic Research Working Paper No. 5543, 1996.

6 Yeh CC. The tobacco war of Taiwan. Taipei, Taiwan: John Tung Foundation, 2002.

7 Albert D. [Taiwan]. R.J. Reynolds, 27 Jan 1992. Bates No. 515011058/1059 http://legacy.library.ucsf.edu/tid/slg03d00 (Accessed 25 Mar, 2004).

8 Monopoly Bureau. Report from tobacco and alcohol consumption survey in Taiwan area. Taipei, Taiwan: Taiwan Tobacco and Wine Monopoly Bureau 1964-1996.

9 Cheng TY, Wen CP, Tsai MC, et al. The current status of smoking behavior in Taiwan: data analysis from National Health Interview Survey in 2001 (in Chinese). Taiwan J Public Health 2003;22(6)

10 Directorate-General of Budget, Accounting and Statistics. Consumption of tobacco, wine and betel nuts. Statistical yearbook of the Republic of China Taipei, Taiwan: Directorate-General of Budget, Accounting and Statistics (DGBAS), Executive Yuan, 2002.

11 Directorate-General of Budget, Accounting and Statistics. Statistical yearbook of importation and exportation. Taipei, Taiwan: Directorate-General of Budget Accounting and Statistics (DGBAS), Executive Yuan, Taiwan; 1980-2002.

12 American Cancer Society. Tobacco control country profiles. Atlanta, Georgia: American Cancer Society; 2000-03.

13 Glantz S, Slade J, Bero L. The cigarette papers, University of California Press, 1996.http://legacy.library.ucsf.edu/index.html (Accessed Aug 27, 2003).

14 Chapman S, Vermeer R. Tobacco marketing monopolies that advertise. Lancet 1985;i:758.

15 US Department of Health and Human Services. Section 301 of the Trade Act of 1974. In: Reducing tobacco use: a report of the Surgeon General. Atlanta: Office on Smoking and Health, 2000:312-5.

16 Wen CP, Cheng TY, Eriksen MP. How opening the cigarette market led to an increase in betel quid use in Taiwan. Public Health (in press).

17 Survey Research Taiwan. Parliament ad test (FGD). February 1993. Bates No. 2504021537/1575. Philip Morris. http://legacy.library.ucsf.edu/tid/ rer19e00 (Accessed Aug 27, 2003).
18 Philip Morris. Marlboro new concept test - Taipei. June 1993. Bates No. 2504021480/1534. http://legacy.library.ucsf.edu/tid/yer19e00 (Accessed Aug 27, 2003)

19 PMI Marketing Services. Philip Morris Asia Region Overview. March, 1990. Bates No. 2501081755/1849. Philip Morris. http://legacy.library.ucsf.edu/ $\mathrm{tid} /$ zac29e00 (Accessed Aug 27, 2003).

20 Michael Normile Marketing. Taiwan cigarette market opportunity study. May 1989. Bates No. 2504027959/8084. Philip Morris. http:// legacy.library.ucsf.edu/tid/vdu19e00 (Accessed Aug 27, 2003)

21 Kwong D. PMAI Taiwan. Key Account Program for Convenience Store. October 24, 1989. Bates No. 2504009909/9910. Philip Morris. http:// legacy.library.ucsf.edu/tid/emq19e00 (Accessed Aug 27, 2003).

22 Kozlowski LT, Pillitteri JL. Beliefs about "Light" and "Ultra Light" cigarettes and efforts to change those beliefs: an overview of early efforts and published research. Tobacco Control 2001;10(suppl I):i12-6.

23 US Department of Health and Human Services. Risks associated with smoking cigarettes with low tar machine-measured yields of tar and nicotine. Smoking and Tobacco Control Monograph 13. Bethesda, Maryland: US Department of Health and Human Services, National Institutes of Health, National Cancer Institute, NIH, 2001.

24 Philip Morris. Special analysis - a new Virginia brand - Taiwan. August 1991. Bates No. 2504027887/7907. http://legacy.library.ucsf.edu/tid/deu19e00 (Accessed Aug 27, 2003).

25 Philip Morris. Virginia Slims below-the-line programs update Hong Kong Taiwan Japan Korea. August, 1990. Bates No. 2500152276/2329. http:// legacy.library.ucsf.edu/tid/sfn 19 e00 (Accessed Aug 27, 2003)

26 RJ Reynolds Tobacco International. [Memo from Don Albert to Brenda Follmer] May 19, 1993. Bates no.515228723/8723. RJ Reynolds. http:// legacy.library.ucsf.edu/tid/amb03d00 (Accessed Aug 27, 2003).

27 Pollay RW, Dewhirst T. The dark side of marketing seemingly "Light" cigarettes: successful images and failed fact. Tobacco Contro 2002:11(suppl I):i18-31.

28 Hsieh CR, Hu TW, Lin CJ. The demand for cigarettes in Taiwan: Domestic versus imported cigarettes. Contemporary Economic Policy 1999; 17:223-34. 29 Philip Morris International. Cigarette ventilation. 2004. http:// www.philipmorrisinternational.com/pages/eng/smoking/cig_ventilation.asp (Accessed Nov 10, 2004)

30 Philip Morris Asia Inc. Asia Region Cigarette Information Report Taiwan Market Sample \# 3. Bates No. 2055649614/9629, 1995. http:// legacy.library.ucsf.edu/tid/ebx87e00 (Accessed Nov 15, 2004).

31 Will NL, Connell CT, Smith JN. Asia Region Cigarette Information Report Taiwan Market Sample \# 7. Bates No. 2055661 108/1115. Philip Morris, 1994. http://legacy.library.ucsf.edu/tid/qes96e00 (Accessed Nov 15, 2004).

32 Chong F. Taiwan Market Monitor-Quantitative Study Final Report (MRD Int'| 1987-21). Bates No. 670927513/7524. Brown \& Williamson Tobacco Corporation, 1987. http://legacy.library.ucsf.edu/tid/euf90f00 (Accessed Nov 15, 2004)

33 Philip Morris. TAIWAN OB. 1994. Bates No.2504032701/2750. http:// legacy.library.ucsf.edu/tid/vba42e00 (Accessed Nov 10, 2004).

34 Noel J. [Taiwan Talks]. Brown and Williamson, $22 \mathrm{Apr}$ 1988. Bates No. 632000664/0674. http://legacy.library.ucsf.edu/tid/gge70f00 (Accessed Nov 10, 2004)

35 Chen KT, Chen CJ, Fagot-Campagna A, et al. Tobacco, betel quid, alcohol, and illicit drug use among 13- to 35-year-olds in I-Lan, rural Taiwan: prevalence and risk factors. Am J Public Health 2001;91:1130-4.

36 Wen CP, Tsai SP, Cheng TY, et al. Uncovering the relation between betel quid chewing and cigarette smoking in Taiwan. Tobacco Control 2005; 14(suppl I):i16-22.

37 Directorate-General of Budget Accounting and Statistics. Consumption of tobacco, wine and betel nuts. Statistical yearbook of the Republic of China Taipei, Taiwan: Directorate-General of Budget, Accounting and Statistics (DGBAS), Executive Yuan, 2002

38 Department of Health. Vital statistics in Taiwan. Taipei, Taiwan: Department of Health, Executive Yuan, Taiwan; 1975-2002.

39 British American Tobacco. [Project Hurricane-Taiwan]. 17 Nov 1992. Bates No. 301633488 / 3494. http://www.library.ucsf.edu/tobacco/batco/html/ 14700/14773/otherpages/allpages.html (Accessed 25 Mar, 2004).

40 Ivey T. [Memo from T. Ivey Enclosing Market Profile]. British American Tobacco, 9 Dec 1992. Bates No. 500032093/2097. http:// www.library.ucsf.edu/tobacco/batco/html/15200/15275/otherpages/ allpages.html (Accessed Mar 25, 2004)

41 Barnes JA. [RJR Hong Kong: Management Visit to Asia Pacific]. R. J. Reynolds., 18 Apr. 1995. Bates No. 513214462 / 4639. http:// legacy.library.ucsf.edu/tid/jin30d00 (Accessed Mar 25, 2004)

42 Kessler J. Taiwan. R. J. Reynolds, 1989. Bates No.512541654/1724. http:// legacy.library.ucsf.edu/tid/mbm33d00 (Accessed Nov 10, 2004).

43 Foreman D. [Taiwan]. R.J. Reynolds, 18 Sep 1992. Bates No. 515011068 / 1069. http://legacy.library.ucsf.edu/tid/wlg03d00 (Accessed Nov 10, 2004)

44 Wen CP. The Taiwan tobacco atlas. Taipei, Taiwan: United Medial Foundation and National Health Research Institutes, 2004.

45 Bureau of Health Promotion. Tobacco control in Taiwan-2003. Taichung, Taiwan: Bureau of Health Promotion, Department of Health, Taiwan, 2003. 46 Tobacco and Alcohol Tax Act, Taiwan, 2000.

47 Hu TW, Mao Z. Cigarette taxation in China: lessons from international experiences. Tobacco Control 1997;6:136-40.

48 World Health Organization Mortality Database. WHO Statistical Information System. World Health Organization, 2004. http://www.who.int/whosis/ (Accessed Nov 10, 2004)

49 Shi MS, Hsieh CR. Cigarette demand, cigarette taxation, and anti-smoking: Review of empirical literature and the case of Taiwan. J Social Science and Philosophy 1999;11:301-34. 
50 Ivey T. [Letter from Trevor Ivey to James McNeil Regarding Project Hurricane] British American Tobacco., 16 Nov. 1992. Bates No. 301633498/3499. http://www.library.ucsf.edu/tobacco/batco/html/14700/14774/

otherpages/allpages.html (Accessed Mar 25, 2004).
51 Ivey T. [Letter from Trevor lvey to Mark Syta regarding Project Hurricane Advertising Research]. British American Tobacco., 9 Dec 1992. Bates No. 301633512/3515. http://www.library.ucsf.edu/tobacco/batco/html/ 14700/14775/otherpages/allpages.html (Accessed Mar 25, 2004).

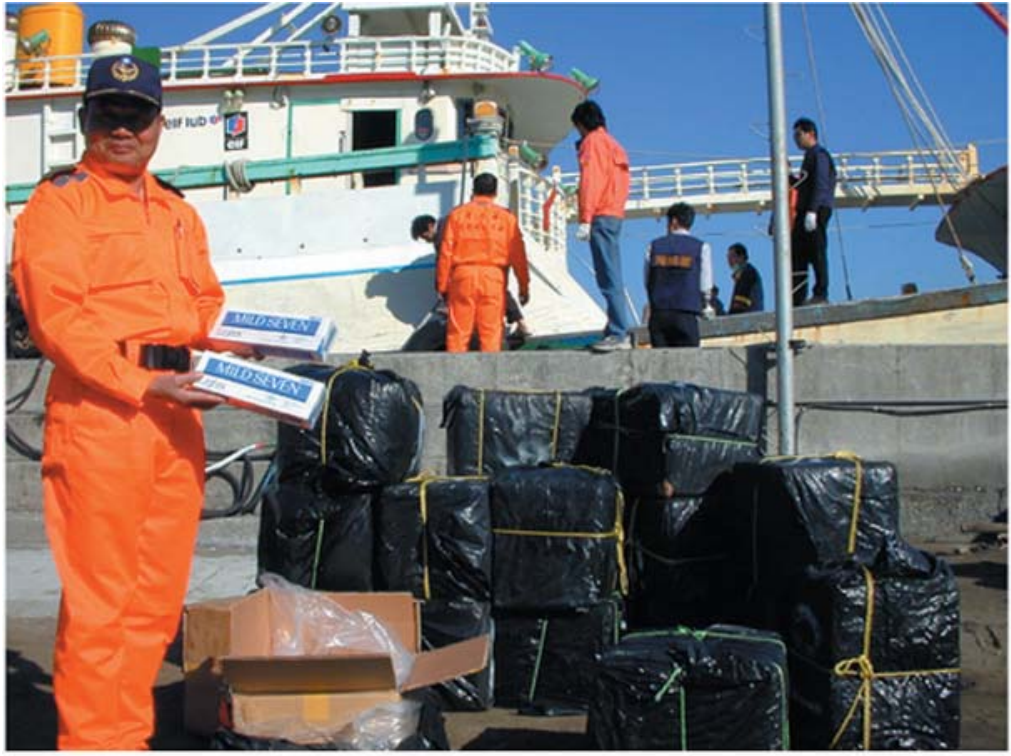

Smuggling seizure: Coast Guard intercepted Japanese Mild Seven cigarettes

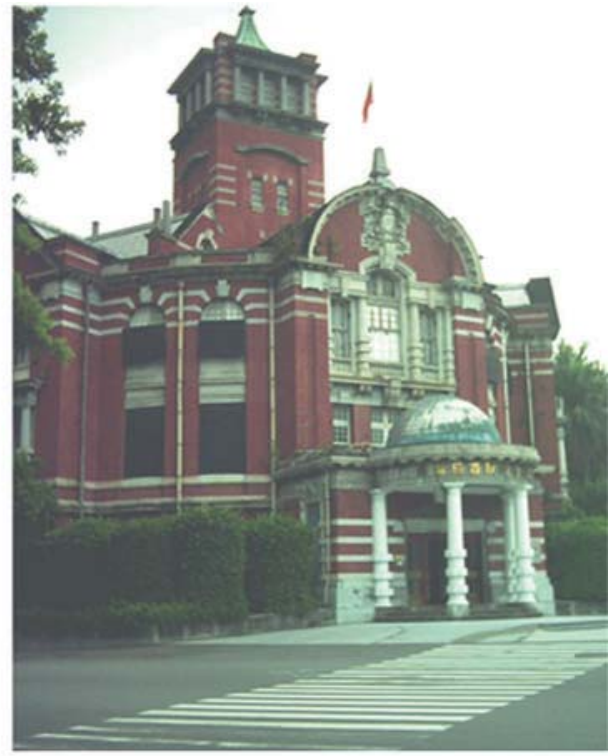

Historical landmark- The Monopoly Bureau building with more than a century of dominance (shown in cover picture)

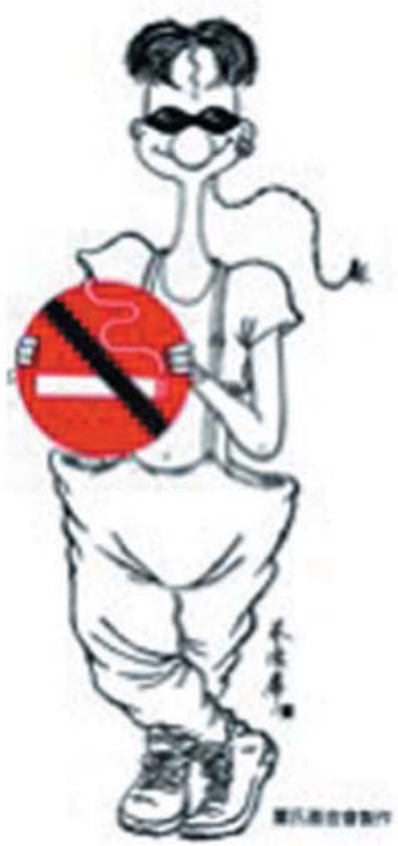

Anti-smoking cartoon celebrity figure in Taiwan

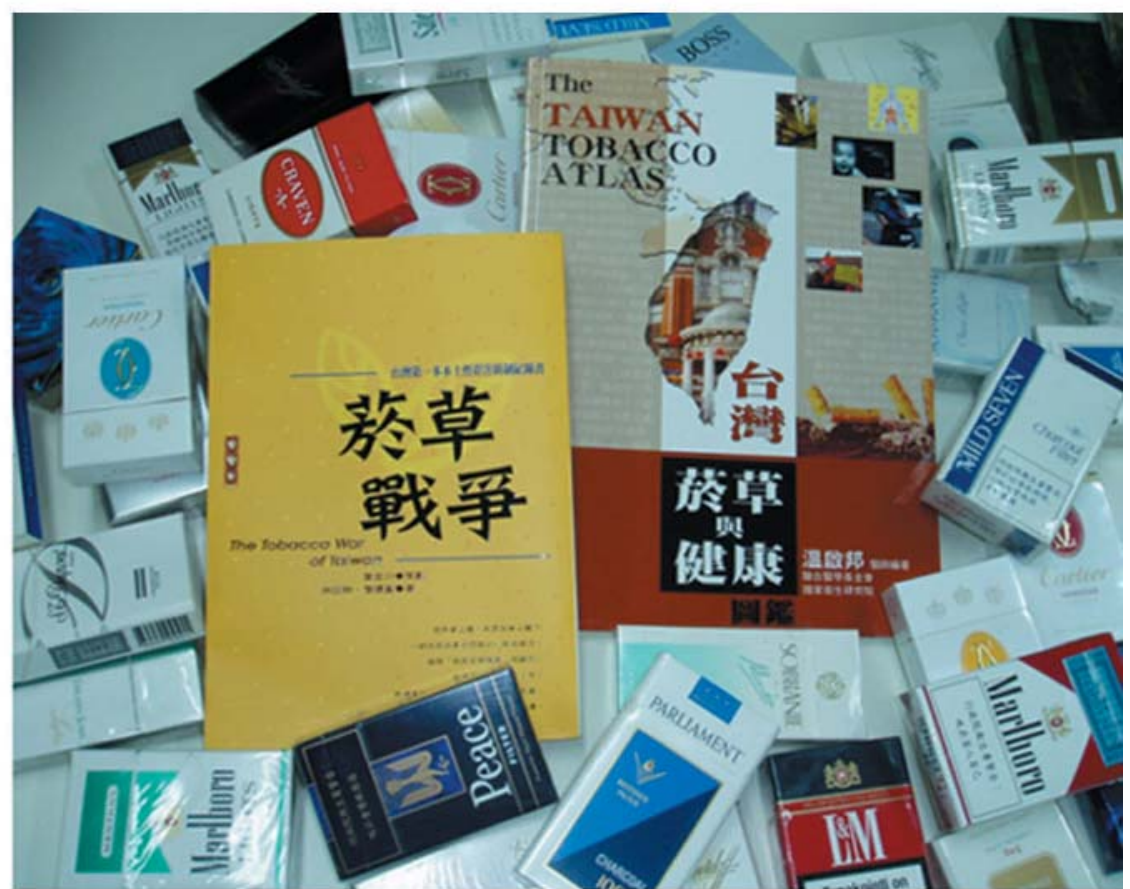

The Tobacco War in Taiwan 